\title{
Customer's Perception and its impact on Market Share of Mobile Communication Industry with special reference to Thanjavur Town
}

\author{
Salomi .S, Prakash .S, Singaravadivel.S, Lakshminarayanan.K
}

\begin{abstract}
Customer fulfillment is a main factor for the business environment. But it is not easy task for the business people. Because trends, preferences, technology are changing from day to day factors. On the other hand, competition is the most important factor, so every business facing this kind of problem. But the fact is one who meets out the customer satisfaction level or to give more than their desire level that company will acquire the 'leadership position' in the market. Now, the above condition repeats in mobile network sector, Indians are very price sensitive customer so who will focus the price sensitive market segment the opportunity is there. Based on the minds of customer the operators are following the strategy, the current trend is said to be "competitors kill strategy" in order to get attention in the minds of Indian customers. In this study focused on the customer's perception towards the new entry of operator into market and how its affect the already existing operators in the market. But the fact is, in the present situation, the network operator faces problems like, political, economical, social and technological problem. One who tackle the situation and satisfy the customer that network operator will retain their level. So this study is about customer perception and satisfaction towards their mobile network.

"Change is the only thing which cannot be change".

Index terms: Leadership Position, Indian Customers,

Competitors
\end{abstract}

\section{INTRODUCTION}

A mobile network is a communication network where the final relation is wireless, before that land line connection was very new and popular owned by the maximum shares of central government, but today the trend is different why because of the privatization, it creates competition among the network service provider. In order to satisfy their customer they are giving attractive packages and offers, but in this study we focused on customer's perception towards the mobile network and how it affects the market share.

\section{A. Importance of telecom sector}

The world today has prepared itself so used to telecommunication that the world would fall down if it was in use away. The basis for the marvelous development of telecommunications is because we needed an enhanced way to transmit messages to each other communication is a hugely vital phase, not only for people about the world, but also for

Revised Manuscript Received on July 05, 2019

S.Salomi, Department of Management studies, Periyar Maniammai Institute of Science \& Technology, Thanjavur,Tamil Nadu, India.

S.Prakash, Department of Business administration, Meenaakshi ramasamy arts \& science College, Ariyalur,Tamil Nadu, India.

S. Singaravadivel, P.G \& Research Department of Commerce, Swami Dayananda college of Arts \& Science, Manjakkudi, Tamil Nadu, India.

K. Lakshminarayanan, P.G \& Research Department of Commerce, Swami Dayananda college of Arts \& Science, Manjakudi, Tamil Nadu, India small and great business. Extensive distance communication has been around for years with the oldest process that can be consider the use of burn signals. With time, methods such as horns became a means of communication. But with time there has been a lot of growth with more superior technologies such as radio, receiver, television $\&$ internet.

\section{B. Evolution of mobile network technology}

Mobile network technology is rising, apparently at an accelerating rate of innovation and adoption. Examining the a long walk taken from $1 \mathrm{G}$ to $4 \mathrm{G}$, the technology had both created new usage patterns and learned from surprising use cases.

$1 \mathrm{G}$ is said to be 1 st Generation Cellular network previous to 1990

$2 \mathrm{G}$ is said to be GSM and GPRS Networks (early1990s) $3 \mathrm{G}$ is said to be Networks (up to $2 \mathrm{Mpbs}$ )

$4 \mathrm{G}$ is said to be High-Speed Mobile Networks (up to 20 Mbps)

5G: Stands for fifth generation is the latest mobile wireless is until now to be set.

C. Growth of network services

1. Telephone services:

In the land line network process optical fiber cable takes position, anyone can communicate a message from one to other person through telephone.

2. Internet services:

With the use of internet a person can send information from one E-mail Id to other Id.

3. Pager communication :

Pagers were just like a machine which was popular around the industry people it helps to get a message alone.

4. Mobile service :

In a wireless mobile service a person who delivers a voice message from one person to another person.

5. SMS service:

With the uses of cellular phone, a person types a text to other person,

6. Data service :

In the present generation Data service take a main role in all over the world.

\section{Definition marketing:}

Marketing is the study of relationship between the company and the customer. The American Marketing Association has defined marketing as "the activity, set

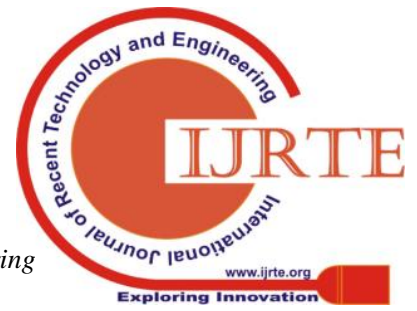


of institutions, and processes for creating, communicating, delivering, and exchanging offerings that have value for customers, clients, partners, and society at large." Marketing is used to create, keep and satisfy the customer. From this definition we clearly understood that the term marketing means as a marketer, one should understand the needs and wants of the people after that deliver the services to the people

\section{E. Digital marketing}

Digital Marketing is the term for the marketing of products or services with the help of digital technologies, mainly on the Internet, media and mobile phones. In this current situation, digital marketing plays a vital role to deliver their services to people.

\section{F. Customer satisfaction:}

Customer satisfaction is a marketing term that measures how products or services supplied by a company meet out or exceed the customer's expectation. It is important because it provides marketers and business owners with a metric that they can use to manage and improve their businesses.

\section{REVIEW OF LITERATURE}

Zafar (2013) examines the impact of the mobile service attributes like call rates, service quality, service availability; promotion and brand image of both the gender's purchasing decision. The result reveals that the male and female consumers have different preference in making the purchase decision to the avail mobile service. The study also discovers that the female consumers are tough to satisfy than the male consumers.

Zohaib Ahmad and Junaid Ahmad (2014) Describe in their study titled Consumer Purchase Behavior in Cellular Service Sector" says that the dominant factors quality, price, promotions, and social factors reflects the latest buying behavior of people or not.

Palaniappan and Sengottaiyan (2015) studied about customer perception found mobile services; say the service providers could focus to retain their existing customer and adding new customer to their basket.

\section{METHODOLOGY}

\section{A. Statement of the problem}

In this study, the problem that are confronted in day to day operations are highlighted like as, Pricing, network coverage, proper services and offers these are the important aspects of the service provider of mobile network operators. In these above aspects only, customer gets attracted towards the network product. Once the customer gets satisfied in these services they won't change their network. But now the situation changed; entry of new network in the market makes the tremendous change, the offers, price, services and all give better than the existing operators, the customer get highly attracted in new product so the customer switch over to new network. Here problem starts this new trend affects the market share of the network.

- Primary data was collected by the researcher with help of structured questionnaire to the mobile users in the Thanjavur town.

- Secondary data collected from mobile network retail outlet and websites. in order to meet out the satisfaction level.

\section{B. Objectives of the study}

Primary Objective

- To analyze the perception of customer towards mobile network in order to identify whether it is increase the market share of the mobile network.

Secondary Objective

- To study the competitive status among the branded mobile networks.

- To analyze and measure the market share among the all mobile networks.

- To probe about the customer satisfaction among the mobile networks.

- To summarize about the problems faced by all network companies.

\section{SAMPLING METHODS}

- From the total population of mobile network user in Thanjavur city, 220 respondents are selected from the total population.

SAMPLING TECHNIQUES USED

- Convenient sampling technique has been used in data collection process.

IV. DATA ANALYSIS AND INTREPRETATION:

A. Mean analysis

\begin{tabular}{|l|c|}
\hline \multicolumn{1}{|c|}{ Factor } & $\begin{array}{c}\text { Mean } \\
\text { value }\end{array}$ \\
\hline Price And Offers Provided By Service Provider & 3.73 \\
\hline Rating For Network Service Provider & 3.39 \\
\hline Connectivity Provide By Service Provider & 3.39 \\
\hline Connectivity Problem Faced Frequently & 2.80 \\
\hline Quality Of The Network & 3.41 \\
\hline Special Offer Provided By Network & 3.67 \\
\hline Cost Of Calls And Text Messages & 3.25 \\
\hline Reputation Of Network & 3.79 \\
\hline Appearance Of Service Centre & 3.79 \\
\hline $\begin{array}{l}\text { AVAILABILITY OF NETWORK PRODUCTS } \\
\text { (SIM CARD, TOP UP CARD, Etc) }\end{array}$ & 3.88 \\
\hline Uniqueness Or Features Of Network & 3.47 \\
\hline
\end{tabular}

Inference

From the above mean analysis it is found that, all the factor of the respondents opinions are between neutral and satisfaction except connectivity problem.

\section{B. CHI-SQUARE TESTS}

Hypothesis: Age of the respondent and psychographic factor.

$\mathrm{H} 0$ : There is no significant relationship between Age of the respondent and psychographic factor.

H1: There is a significant relationship between Age of the respondent and psychographic factor.

\begin{tabular}{|c|c|c|c|}
\hline $\begin{array}{c}\text { AGE * } \\
\text { PSYCHOGRAPHIC } \\
\text { FACTOR }\end{array}$ & Value & DF & $\begin{array}{c}\text { Asymp. Sig. } \\
\text { (2-Sided) }\end{array}$ \\
\hline $\begin{array}{l}\text { Spending of usage for } \\
\text { mobile network }\end{array}$ & $36.723^{\mathrm{A}}$ & 12 & .000 \\
\hline
\end{tabular}




\begin{tabular}{|l|c|c|c|}
\hline $\begin{array}{l}\text { Awareness about } \\
\text { schemes provided by } \\
\text { service provider }\end{array}$ & $41.785^{\mathrm{A}}$ & 8 & .000 \\
\hline $\begin{array}{l}\text { Uses of value added } \\
\text { services }\end{array}$ & $\begin{array}{c}128.621 \\
\mathrm{~A}\end{array}$ & 12 & .000 \\
\hline $\begin{array}{l}\text { Offers provided by } \\
\text { service provider }\end{array}$ & $42.716^{\mathrm{A}}$ & 12 & .000 \\
\hline $\begin{array}{l}\text { Customer services } \\
\text { provided by service } \\
\text { provider }\end{array}$ & $68.348^{\mathrm{A}}$ & 12 & .000 \\
\hline $\begin{array}{l}\text { Connectivity provide } \\
\text { by service provider }\end{array}$ & $78.360^{\mathrm{A}}$ & 16 & .000 \\
\hline $\begin{array}{l}\text { Connectivity problem } \\
\text { faced frequently }\end{array}$ & $\begin{array}{c}106.984 \\
\mathrm{~A}\end{array}$ & 16 & .000 \\
\hline
\end{tabular}

Result

From the above table it is inferred that the calculated $\mathrm{P}$ value $(0.00)$ the entire factor was lesser than $(0.05)$, hence null hypothesis $(\mathrm{H} 0)$ is rejected and the alternative hypothesis (H1) is accepted. There is a significant relationship between Age of the respondent and psychographic factor.

Hypothesis: Age of the respondent and psychographic factor.

H0: There is no significant relationship between Occupationof the respondent and psychographic factor.

H1: There is a significant relationship between

Occupation of the Respondent and Psychographic Factor.

\begin{tabular}{|l|c|c|c|}
\hline \multicolumn{1}{|c|}{$\begin{array}{c}\text { Occupation * Psychographic } \\
\text { factor }\end{array}$} & Value & Df & $\begin{array}{c}\text { Asymp } \\
\text {. Sig. } \\
(\mathbf{2}-\mathbf{s i d e} \\
\mathbf{d})\end{array}$ \\
\hline $\begin{array}{l}\text { Spending of usage for mobile } \\
\text { network }\end{array}$ & $10.095^{\mathrm{a}}$ & 12 & .608 \\
\hline $\begin{array}{l}\text { Awareness about schemes provided } \\
\text { by service provider }\end{array}$ & $23.463^{\mathrm{a}}$ & 8 & .003 \\
\hline $\begin{array}{l}\text { Uses of value added services } \\
\text { Offers provided by service provider }\end{array}$ & $40.468^{\mathrm{a}}$ & 12 & .000 \\
\hline $\begin{array}{l}\text { Customer services provided by } \\
\text { service provider }\end{array}$ & 117.449 & 12 & .000 \\
\hline $\begin{array}{l}\text { Connectivity provide by service } \\
\text { provider }\end{array}$ & $83.224^{\mathrm{a}}$ & 12 & .000 \\
\hline $\begin{array}{l}\text { Connectivity problem faced } \\
\text { frequently }\end{array}$ & $199.941^{\mathrm{a}}$ & 16 & .000 \\
\hline
\end{tabular}

Result

From the above table it is inferred that the calculated $\mathrm{P}$ value (0.00) the 6 factor was lesser than (0.05) except spending of usage for mobile network, hence null hypothesis (H0) is rejected and the alternative hypothesis (H1) is accepted. There is a significant relationship between Occupationof the respondent and psychographic factor.

V. Discussion on findings

Chi-square Test

A. In age factor compared with their spending in usage for mobile network, it was found low age people spending more min low rate plan.

B. In age factor compared with awareness about scheme provided by service provider, It was found people in the age of 36-45 yrs got less awareness in the service provider's scheme.

C. In age factor compared with uses of value added services, It was found people in the age of 26-35yrs somewhat less in the usage of network service and $36-45 y$ rs of people low in the usage of internet access.

D. In age factor compared with prices and offers provided by mobile network, it was found people in the age of 26-35 yrs dissatisfied in the price and offers of their network.

E. In age factor compared with service provided by network, It was found people in the age of below 25 yrs got dissatisfied.

F. In age factor compared with connectivity provided by service provider, it was found people in the age of below $25 \mathrm{yrs}$ and in the age of 26-35yrs got dissatisfied.

G. In age factor compared with connectivity problem faced by customers, it was found people in the age of below $25 \mathrm{yrs}$ and in the age of 26-35yrs got dissatisfied, faced problem like network busy, not getting range, and voice problem.

H. In occupation factor compared with their spending in usage for mobile network, there is no significant relationship with spending of usage for mobile network.

I. In occupation factor compared with awareness about scheme provided by service provider, It was found scheme not familiar to people like student, employee.

J. In occupation factor compared with uses of value added services, in this case majority response is only in Internet access.

K. In occupation factor compared with prices and offers provided by mobile network, in this respondent gave moderate response.

L. In occupation factor compared with service provided by network, in student circle got dissatisfied.

M.In occupation factor compared with connectivity provided by service provider, in this private employee got highly dissatisfied.

N. In occupation factor compared with connectivity problem faced by customers, in the category of private employee faced problem in some inside region.

\section{SUGGESTIONS}

\section{A. Pricing}

Here already insist about price sensitive market segment, the one who give maximum offers at very minimum price the mobile network user prefers that one, because it's not a difficult thing to change network from one network to another in this present situation. So, price plays an important role.

\section{B. Schemes and offers}

If you think schemes like offers, prepaid or post paid packages it's just like one who wants to use particular network scheme they use it but it is not like that, many of the people have not awareness about schemes offered by the network provider why because the offers are differ from one

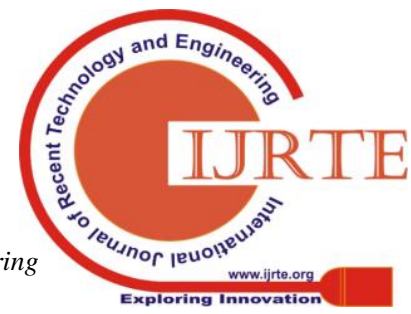


user to another and changing day by day, like this only all existing networks are following but now the case changed entry of JIO changed the old concept, it fetch up all customers under one roof that means every one come under one particular scheme. So there is no confusion state between JIO users and the company gain large amount by applying this process.

\section{Connectivity}

For voice calls, internet access connectivity is an important matter, if user prefer particular network because of, getting good network while of making a call that time if user getting the trouble means definitely it creates negative impression towards the network. In that time, user thinks for better network, so they will jump over to another network. In this situation there is lot of chance to get decline in market share of the network.

\section{Value added services}

Services like SMS, Voice mail, Call Forwarding, Caller tunes and Internet access facilities these are facilities provided by the service provider in that some of the services are get outdated because of technological growth. In this current situation Internet play all roles in the way of by using internet we make a call, or sending messages, internet access or any detection purpose like that so the network company should concentrate in giving better quality of internet facilities to the users in order to retain market share.

\section{E. Advertisement}

Advertisement is the important part of the business through advertisement only the company will communicate message about their product to people. If there is no advertisement, the people will forget the product. The above situation now happening in the mobile network area, why because many networks are not concentrate in advertising segment, it's quite opposite in their entry level into the network market.

\section{F. Customer Satisfaction}

\section{i. Reputation of the network}

The brand name is the important to maintain the position in the market the brand name get popular while the customer feels satisfaction in the product. In this time only the reputation of network will get increase.

\section{ii. Customer Care}

If there is a problem there is a solution, like that networking is not a easy thing there is always some problem arising this is not a users work to solve the problem in networking so service provider will clear the problem but approaching the customer care is difficult for aged people or unskilled people they not even don't know how to contact there is so many procedures to connect with them.

\section{iii. Product availability}

SIM cards, Top up cards etc... these are important products for network on the other hand while the time of recharging some prefers online recharge but many of them visit retail outlet or any mini store for recharging purpose here in the Thanjavur town, but the fact is many user facing the problem like searching for place to recharge that means product availability is very low for particular network. So all networks including government undertaking network also concentrate in this segment to think and improve these things to reach easily to the customer.

iv. Appearance of the service centre

In the case of mobile network all services are come under intangible service, but the only services the people can able to see is service centre and service person appearance if the customer feel the service person has pleasing personality means definitely customer get attracted. So in this time customer feel loyalty towards the brand of the product.

At last, if the network companies will concentrate these above areas definitely that company set a bench mark to others. Customer satisfaction is only thing will build up the brand image in order to improve the market share of the network.

\section{CONCLUSION}

In this present study clearly explores about that there is technological development, marketing strategies of mobile operators, providing unimaginable facilities and offers to the mobile users these things are to attract customer and try to increase the satisfaction level of them, and it's only for growth of their own company. But my question is why these things are following by private people alone? Government undertaking sector is there, then why they are absent to provide benefits equal to private mobile network operator to the customer. "TRAI" is the framing authority to frames the rules and regulations of the telecom industries, it is the government regulatory body but benefits are gained by the private people. Government is only for the people, then why government sector failed to do give more beneficial things to the people like private sector. If government give more valuable offers and technological advancement benefits to user, people definitely prefers government's network services. If it is happen means its benefit for both the government and people in our country. And it will support the economic growth of the country.

\section{REFERENCES}

1. Kothari. C.R (2004): 'Research Methodology Methods \& Techniques',

2. Network Company's official website.

3. New Age International Publishers, New Delhi, 2nd Edition.

4. Palaniappan \& Sengottaiyan, Customer perception towards mobile services - a case study of BSNL at bavani town, International Research Journal of Engineering and Technology (IRJET)Volume: 02 Issue: 04 | July-2015 E-ISSN: 2395-0056.

5. Paulrajan R, Harish R. Service Quality and Customers Preference of Cellular Mobile Service Providers. Journal of Technology Management \& Innovation 2011; 6(1): 38-45.

6. Philip Kotler $14^{\text {th }}$ edition: 'Marketing Management'.

7. Prentice Hall of India Private Limited, New Delhi, 7th Edition.

8. Richard I. Levin, David S. Rubin (2004): 'Statistics for Management',

9. Telecom Retrieved from The Economic Times on

10. Z Ahmad, J Ahmad. "Consumer Purchase Behavior in Cellular Service Sector of Pakistan", IOSR Journal of Business and Management, vol. 16(5), 2014, pp 62-75. 